and possibly an exciting model for the study of factors which may control and regulate the formed erements of the peripheral blood.

We wish to thank the nursing staff of the renal unit at Fulham Hospital for their help with these studies and Mr. M. G. Ventom for valuable technical assistance.
REFERENCES

Bennett, I. L., and Beeson, P. B. (1950). Medicine, 29, 365.

Curtis, J. R et al (1969). Quarterly 7ournal of Medicine, 38, 49.

Kaplow, L. S., and Goffinet, J. A. (1968), Journal of the American Medical Association, 203, 1135 .

Kusserow, B. K., and Larrow, R. (1968). Transactions. American Society for Artificial Internal Organs, 14, 261.

Leusen, I. R., and Essex, H. E. (1953). American fournal of Physiology, 172,231 .

\title{
Venous Effects of Oral Contraceptives
}

\author{
ELLEN C. G. GRANT,* M.B., CH.B., D.oBST.R.C.o.G.
}

Summary : In a five-year analysis of an oral contracep$\checkmark$ tive trial by the Council for the Investigation of Fertility Control venous effects were the third most troublesome group of side-effects with both combined and sequential therapy. Vein complaints, leg cramps, and thrombophlebitis were significantly more frequent with the combined preparations that contained a relatively low dose of progestogen and a high dose of oestrogen than with the other groups tested. No cases of thrombophlebitis occurred in women taking the strongly oestrogenic sequential groups.

Histological examination of uterine curettings showed that most progestogenic combined preparations were associated with a high incidence of dilated endometrial sinusoids, while the oestrogenic sequential regimens and low-dose progestogen-only regimens had a low incidence. The incidence of stromal condensation round the sinusoids correlated with the incidence of leg cramps, and these effects appeared to be specific for each preparation tested.

\section{Introduction}

Since 1962 the possible association between oral contraceptives and thromboembolic disease has aroused much interest and conflict of opinion. No statistically significant increase in the overall death rate from thromboembolic conditions was found by the U.S. Food and Drug Administration in 1963 and again in 1966, despite the large increase in the number of users of oral contraceptives. A subcommittee of the Medical Research Council (1967), however, published the preliminary results of three investigations and concluded that there was a causal association between oral contraceptive use and thromboembolic disease. The completed results showed a significant increase in the death rate from pulmonary embolism and cerebral thrombosis among oral contraceptive users, the risk being twice as high in women over 35 (Inman and Vessey, 1968). Vessey and Doll (1968) calculated that the likelihood of hospital admission for venous thromboembolism is about nine times greater in women taking oral contraceptives than in those who do not.

Changes in certain blood-coagulation factors have been reported among oral contraceptive users, but no relation could be proved at present between the changes observed and the occurrence of thrombophlebitis (Mears, 1965 and Drill, 1966). In addition to changes in the blood, clotting also depends on changes in both blood flow and vessel walls.

\footnotetext{
* Lately Medical Officer, Council for the Investigation of Fertility Contrcl, .27-35 Mortimer Street, London W.1
}

In our laboratory the appearance of endometrial arterioles and sinusoids in uterine currettings have been examined as part of the trial conducted by the Council for the Investigation of Fertility Control, which began in 1961 to evaluate new oral contraceptives. The clinical effect of the various progestogen/ oestrogen compounds depended on their hormone strengths and balance (Mears, 1967). Grant (1967) classified the compounds into three groups according to their endometrial effects and break-through bleeding incidence.

Group 1. Strongly Progestogenic.-These have a short growth phase, with subnuclear vacuoles from days 8 to 11 , and a prolonged atrophic or postsecretory phase. They have a low break-through bleeding incidence ( 0 to $3 \%$ of cycles).

Group 2. Intermediate.-These have variable growth, secretory, and atrophic phases with maximum subnuclear vacuoles between days 8 and 20 . The break-through bleeding incidence varies from 4 to $40 \%$ of cycles according to the length of the secretory phase.

Group 3. Strongly Oestrogenic (Sequential Regimens).-These produce more growth and secretion than normal over a longer period but no postsecretory phase. They also have a low break-through bleeding incidence of 0 to $5 \%$ of cycles.

All predominantly progestogenic oral contraceptives produce a similar endometrial pattern. Throughout most of the cycle the glands are small and inactive and the endometrium becomes progressively more atrophic with prolonged therapy. This makes it difficult to obtain specimens from every woman. Each formulation, however, appears to have a specific effect on vascular development throughout the cycle-irrespective of cycle day-which may be different from that of other compounds with a similar hormone balance, break-through bleeding incidence, and endometrial pattern.

While arteriole development was found to be specific for each formulation and corresponded with the first-year headache incidence (Grant, 1968), mood changes-in particular depression and loss of libido-were related to hormone balance, and were significantly more frequent with strongly progestogenic compounds containing a low dose of ethinyloestradiol (Grant and Pryse-Davies, 1968). The incidence of the third most common group of side-effects-vein changes and leg crampsvaries with each formulation but is also influenced by overall hormone balance as is described in this paper. The effect of steroids on the endometrial sinusoids is also described.

\section{Subjects and Methods}

The organization and clinic routine of a clinical trial conducted by the Council for the Investigation of Fertility Control has been described in detail by Mears (1961). The volunteers 
had to be healthy, fertile, under the age of 40 years at the time of beginning the trial, and to have had no previous history of thromboembolic disease. At the central clinic a small number of patients were given new formulations for variable periods of time, during which they attended the clinic every three months and were kept under close observation. The preparations were given consecutively under code numbers without the women being selected with regard to age or parity.
After five years an analysis of vein complaints and leg cramps was made. The products tested, the number of women enrolled on each, the duration of each trial, and the cycles completed at the time of analysis are summarized in Tables I and II. A total of 797 women received one or more of 34 oral contraceptives, giving a treatment experience of 1,217 women. Most patients had a break of at least two or three months before beginning a second preparation.

TABLE I.-Oral Contraceptive Compounds Containing Ethinyloestradiol

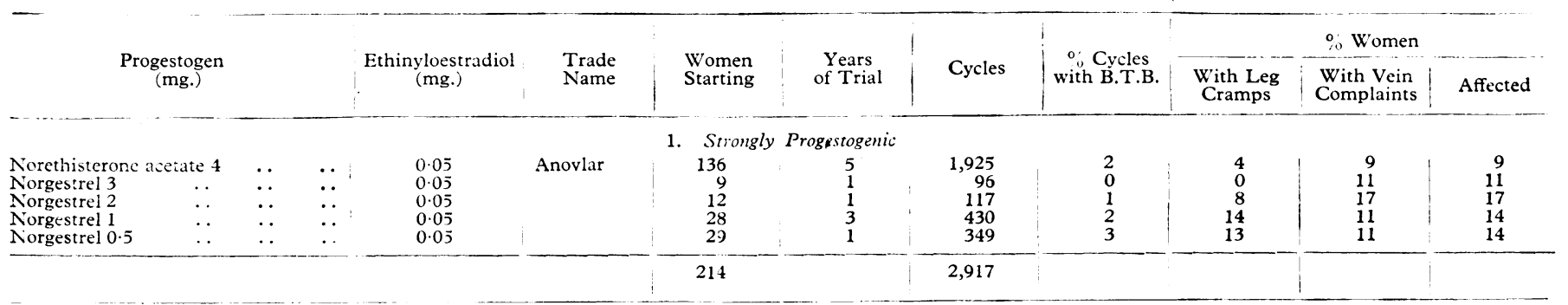

$\begin{array}{lllll}\text { Norgestrel } 0.025 & \ldots & \ldots & \ldots & 0.05\end{array}$

$\begin{array}{lllll}\text { Norgestrel } 0.025 & \ldots & \ldots & . & 0.05 \\ \text { Norgestrel } 0.1 & \ldots & \ldots & \ldots & 0.05\end{array}$

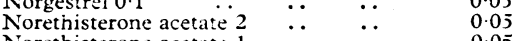

$\begin{array}{llll}\text { Norethisterone acetate } 1 & \cdots & \cdots & 0.05 \\ \text { Nothen }\end{array}$

$\begin{array}{llll}\text { Norethisterone acetate } 1 & \ldots & \ldots & 0.075 \\ \text { Norethisterone acetate } 1 & \ldots & \ldots & 0.09\end{array}$

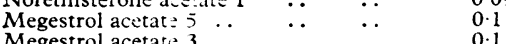

$\begin{array}{lllll}\text { Megestrol acetate } 3 & \ldots & \ldots & \cdots & 0 \cdot 1 \\ \text { Megestrol acetate } 4 & \ldots & \ldots & \ldots & 0 \cdot 05\end{array}$

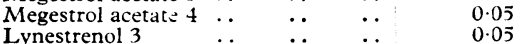

$\begin{array}{llllll}\text { Lynestrenol } 3 & \ldots & \ldots & \cdots & 0.05 \\ \text { Lynestrenol } 2 & \ldots & \ldots & \ldots & 0.05\end{array}$

Norlestrin
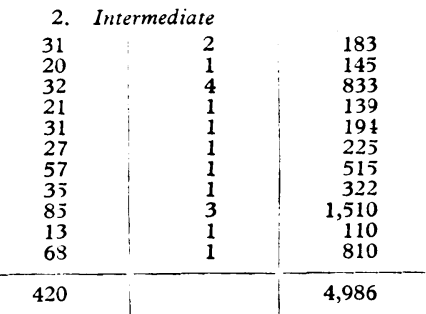

10
30
6
26
8
4
8
20
10
4
6

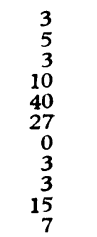

13
10
3
19
32
31
2
8
6
23
6

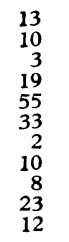

3. Oestrogenic: Sequential Preparations

\begin{tabular}{|c|c|c|c|c|c|c|c|}
\hline & Women & $\begin{array}{l}\text { Years } \\
\text { of Trial }\end{array}$ & Cycles & $\begin{array}{c}\% \text { Cycles } \\
\text { with B.T.B. }\end{array}$ & $\begin{array}{c}\text { Women with } \\
\text { Leg } \\
\text { Cramps } \\
(\%)\end{array}$ & $\begin{array}{c}\text { Women } \\
\text { with Vein } \\
\text { Complaints } \\
\left(\begin{array}{c}0 \\
10\end{array}\right)\end{array}$ & $\begin{array}{c}\text { Women } \\
\text { Affected } \\
\left(\begin{array}{l}0 \\
0\end{array}\right)\end{array}$ \\
\hline \multirow{7}{*}{ 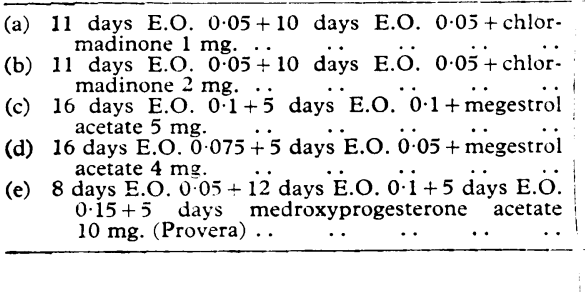 } & 24 & 1 & 140 & 5 & 4 & 8 & 8 \\
\hline & 25 & 1 & 137 & 3 & 4 & 4 & 8 \\
\hline & 84 & 2 & 1,249 & 0.5 & 2 & 3 & 4 \\
\hline & 49 & 2 & 375 & 4 & 4 & 4 & 4 \\
\hline & & & & & & & \\
\hline & 19 & 2 & 174 & 0 & 10 & 5 & 10 \\
\hline & 201 & & 2,275 & & & & \\
\hline
\end{tabular}

TABLE II.-Oral Contraceptive Compounds Containing Mestranol

\begin{tabular}{|c|c|c|c|c|c|c|c|c|c|}
\hline $\begin{array}{c}\text { Progestogen } \\
\text { (mg.) }\end{array}$ & $\begin{array}{c}\text { Mestranol } \\
(\mathrm{mg} .)\end{array}$ & $\begin{array}{l}\text { Trade } \\
\text { Name }\end{array}$ & $\begin{array}{l}\text { Women } \\
\text { Starting }\end{array}$ & $\begin{array}{l}\text { Years } \\
\text { of Trial }\end{array}$ & Cycles & $\begin{array}{c}\text { Cycles } \\
\text { with B.T.B. }\end{array}$ & $\begin{array}{c}\text { Women } \\
\text { with Leg } \\
\text { Cramps } \\
(\%)\end{array}$ & $\begin{array}{c}\text { Women } \\
\text { with Vein } \\
\text { Complaints } \\
\left(\begin{array}{c}0 \\
0\end{array}\right)\end{array}$ & $\begin{array}{c}\text { Women } \\
\text { Affected } \\
(\%)\end{array}$ \\
\hline
\end{tabular}

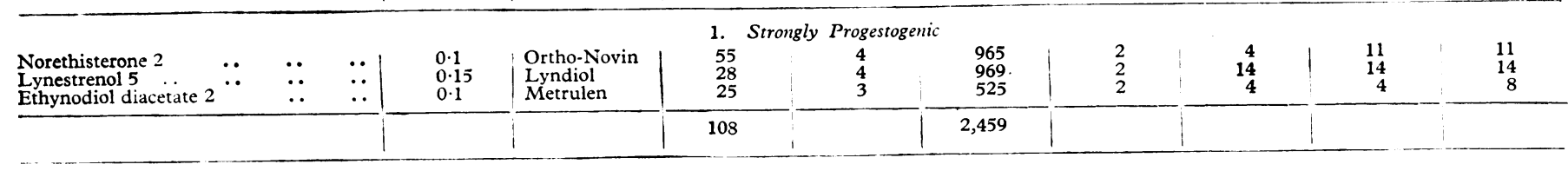

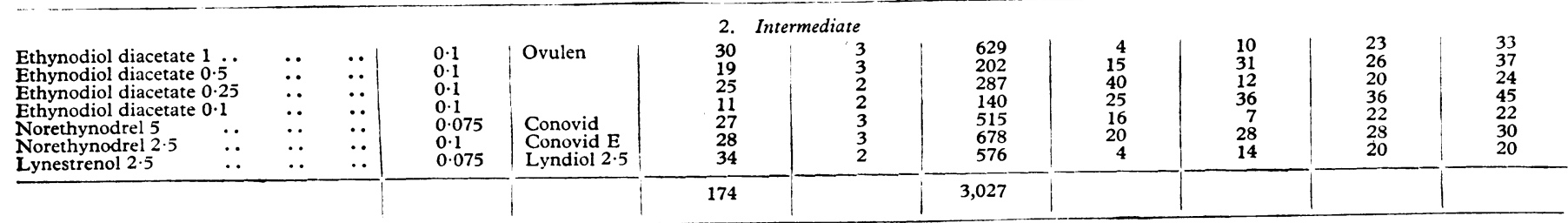

\begin{tabular}{ccc}
\hline & 3. & Oestrogenic: Sequential Preparations \\
93
\end{tabular}

(a) 14 days $M \cdot 0 \cdot 1+7$ days $M \cdot 0 \cdot 1+$ chlormadinone $1 \cdot 5 \mathrm{mg}$. (b) 15 days $M \cdot 0 \cdot 08+5$ days $M \cdot 0 \cdot 08+$ chlormadinone $2 \mathrm{mg}$. 
Endometrial biopsies were obtained from some of the women before the trial and thereafter at six-monthly intervals. No attempt was made to take them at any particular point in the cycle, and it was found that the specimens obtained during treatment with each compound were evenly distributed throughout the cycle. The endometrial specimens were fixed in formalin, sectioned, and stained with haematoxylin and eosin. The slides were numbered and examined without reference to clinical details. The area of the tissue was measured and the glands, stroma, and blood vessels were described. The venules or sinusoids were classified as inconspicuous, or dilated and relatively prominent, or having stromal condensation round their walls.

\section{Effect of Oral Contraceptives on Vein Complaints}

Most of the women found oral contraceptives to be such an efficient and beneficial method of contraception that they would discontinue the trial only because of multiple complaints. The most frequent complaints included headaches, mood changes, and leg troubles (Table III). The distribution of side-effects was the same for both combined and sequential regimens, leg changes being the third most frequent complaint in each case. The follow-up rate was $95 \%$.

\begin{tabular}{|c|c|c|c|c|c|c|c|}
\hline & \multirow[b]{2}{*}{ Women } & \multirow[b]{2}{*}{ Cycles } & \multirow{2}{*}{$\begin{array}{l}\text { With- } \\
\text { drawals } \\
\text { for } \\
\text { Side- } \\
\text { effects }\end{array}$} & \multicolumn{4}{|c|}{$\%$ of Withdrawals With } \\
\hline & & & & $\begin{array}{l}\text { Head- } \\
\text { aches }\end{array}$ & $\begin{array}{c}\text { Mood } \\
\text { Change }\end{array}$ & $\begin{array}{c}\text { Cramps } \\
\text { and Vein } \\
\text { Complaints }\end{array}$ & $\begin{array}{l}\text { Weight } \\
\text { Gain } \\
+3 \mathrm{lb} .\end{array}$ \\
\hline $\begin{array}{l}\text { Combined } \\
\text { preparations } \\
\text { Seauentia! }\end{array}$ & 916 & 13,389 & 277 & 54 & 41 & 29 & 20 \\
\hline preparations & 301 & 3,503 & 64 & 56 & 34 & 20 & 8 \\
\hline
\end{tabular}

The incidence of leg cramps, vein changes, and the total number of women affected with either or both of these complaints on each product are summarized in Tables I and II. The leg cramps occurred mostly in these women who had other vein complaints. The vein changes noted ranged from distended sore veins, increasing varicosities, threadveins, and burst veins to oedema, phlebitis, thrombosis, and pulmonary embolism. The number of women affected varied from 2 to $55 \%$ and appears to depend on the amount and proportion of progestogen and oestrogen in the various products. The incidence of complaints associated with the use of the most strongly progestogenic compounds was low, especially in the first years, whereas that associated with the use of the combined compounds containing a higher dose or proportion of oestrogen was higher. The tablets containing 0.075 and $0.09 \mathrm{mg}$. of ethinyloestradiol had a more immediate effect on veins and leg cramps than the compounds containing ethinyloestradiol $0.05 \mathrm{mg}$.

When the results were grouped according to hormone balance and type of oestrogen (Table IV) the incidence of all leg complaints-including leg cramps-was significantly greater in the 174 women taking the intermediate combined tablets containing mestranol, which have a break-through bleeding incidence of $4 \%$ or more of cycles (group 2), than in those taking the other groups of compounds. The incidence of leg complaints in each group was slightly higher among women who had previously taken other oral contraceptives than among new patients, but was almost the same in the intermediate mestranol group (being $26 \%$ for new patients and $29 \%$ for those taking previous oral contraceptives with an average of $27 \%$ ).

Twelve women developed phlebitis or thrombosis during the five-year analysis and seven of these occurred in the intermediate mestranol group of 174 women who had completed 3,027 cycles, which is 26 cases/1,000 women/year. The overall incidence of 12 cases in 797 new patients completing 16,892 cycles is $9 / 1,000$ women/year, which is significantly higher than an estimated expected incidence of 1-3/year (Drill, 1966 ; Royal College of General Practitioners, 1967) $\left(\chi^{2}=7 \cdot 8\right.$, $\mathrm{P}<0.01)$. The duration of therapy before thrombophlebitis developed was from 12 to 58 cycles. Of the 12 women, six had one product only and nine were taking marketed oral contraceptives (Ovulen, Conovid E, Lyndiol 2.5, Ortho-Novin, and Anovlar). There were nine cases of superficial phlebitis and three of deep-vein thrombosis, with two having signs of pulmonary emboli. No cases of thrombophlebitis were recorded among the women taking the sequential regimens, but at the time of analysis the sequentials had been tested for a relatively short period. Another patient developed hypertension and had a cerebral thrombosis with secondary haemorrhage after 76 cycles on Anovlar.

TABLE IV.-Percentage of Women with Vein Complaints and Leg Cramps

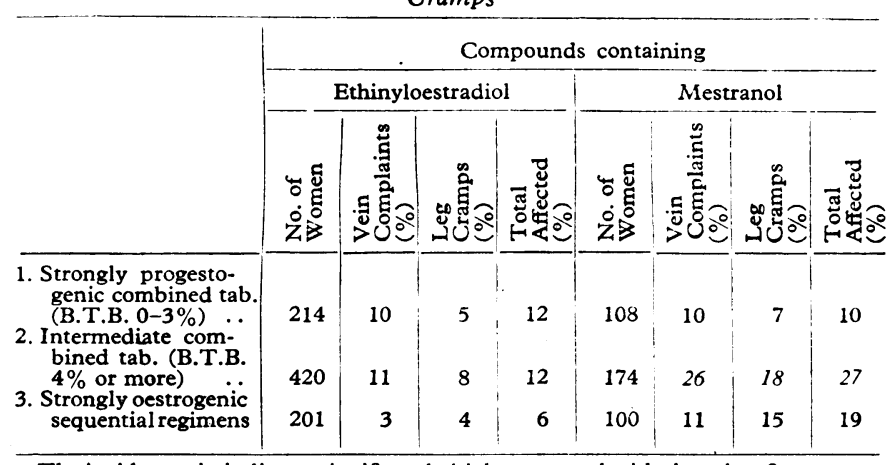

The incidences in italic are significantly high compared with the other five groups. $P<0.001$ in each case.

When medication was discontinued vein conditions of sudden onset, such as painful legs, cramps, and oedema, usually resolved promptly, but conditions taking longer to develop, such as increased varicosities, often showed less immediate improvement. Five of the women developed thrombophlebitis with one pulmonary embolism in the first year after withdrawing because of multiple side-effects. Two of these were after operations and one was postpartum. While most of the volunteers were under 35 years old at the beginning of the trial most of the serious side-effects occurred in women over 35 .

\section{Histological Results}

\section{Endometrial Sinusoids in Untreated Cycles}

To assess the untreated endometrial vasculature 284 pretrial random biopsy specimens were examined : 46 (16\%) had welldeveloped arterioles or artery groups 9 (3\%) had dilated sinusoids. Two were from anovulatory cycles and seven were from late secretory or premenstrual phases. Eleven $(4 \%)$ had stromal condensation round the sinusoids. In the normal cycle sinusoids are inconspicuous in the proliferative and early secretory phases but are distended in the late secretory phase when they are not usually larger or more prominent than the glands. Thus they are inconspicuous for most of the cycle.

\section{Endometrial Sinusoids in Treated Cycles}

Tables V and VI show the incidence of dilated sinusoids in women who had one or more biopsy specimens taken in their first year on a variety of oral contraceptives. Most of the progestogenic combined formulations have a significantly higher incidence of dilated sinusoids than is found in a normal cycle. The sequential strongly oestrogenic regimens have a low incidence of dilated sinusoids. This appears to be the case both for the compounds containing ethinyloestradiol and those containing mestranol. The compounds with the lowest dose of oestrogen, $0.05 \mathrm{mg}$. of ethinyloestradiol, seem to have the 
highest proportion of dilated sinusoids. When the amount of oestrogen (or proportion in the case of ethynodiol diacetate and $0.1 \mathrm{mg}$. of mestranol) is increased the incidence of dilated sinusoids appears to decrease. The incidence of dilated sinusoids did not relate to the incidence of break-through bleeding, vein complaints, or leg cramps. Forty-two specimens from women taking continuous chlormadinone acetate $0.5 \mathrm{mg}$. have also been examined and four $(9 \%)$ had dilated sinusoids. Preliminary studies of other low-dose progestogens also showed a similar small effect on sinusoids in the first year of therapy. TABLE V.-Incidence of Dilated Sinusoids and Leg Symptoms in Women
Who Had Biopsies During the First Year of Therapy on Oral Contraceptive Compounds Containing Ethinyloestradiol

\begin{tabular}{|c|c|c|c|c|c|c|}
\hline \multirow[b]{2}{*}{$\begin{array}{c}\text { Progestogen } \\
\text { (mg.) }\end{array}$} & \multirow{2}{*}{\begin{tabular}{|c} 
Ethinyl- \\
oestra- \\
diol \\
(img.)
\end{tabular}} & \multirow{2}{*}{ Women } & \multirow{2}{*}{$\begin{array}{c}\% \text { \%o } \\
\text { Cycles } \\
\text { with } \\
\text { B.T.B. }\end{array}$} & \multicolumn{3}{|c|}{$\%$ Women with } \\
\hline & & & & $\begin{array}{l}\text { Dilated } \\
\text { Sinu- } \\
\text { sulds }\end{array}$ & $\begin{array}{c}\text { Vein } \\
\text { Com- } \\
\text { plaints }\end{array}$ & $\underset{\text { Cramps }}{\text { Leg }}$ \\
\hline 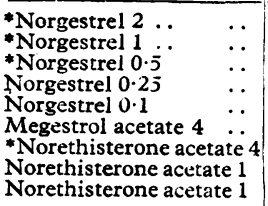 & $\begin{array}{l}0.05 \\
0.05 \\
0.05 \\
0.05 \\
0.05 \\
0.05 \\
0.05 \\
0.075 \\
0.09\end{array}$ & $\begin{array}{l}8 \\
20 \\
17 \\
15 \\
16 \\
26 \\
32 \\
28 \\
20\end{array}$ & $\begin{array}{r}1 \\
2 \\
3 \\
10 \\
40 \\
10 \\
2 \\
8 \\
4\end{array}$ & $\begin{array}{l}62 \\
42 \\
41 \\
53 \\
4.4 \\
58 \\
3 \cdot 4 \\
1 \cdot 4 \\
j\end{array}$ & $\begin{array}{r}25 \\
5 \\
18 \\
20 \\
12 \\
11 \\
y \\
3.4 \\
35\end{array}$ & $\begin{array}{r}12 \\
20 \\
6 \\
6 \\
6 \\
8 \\
6 \\
43 \\
20\end{array}$ \\
\hline $\begin{array}{c}\text { Sequential preparations: } \\
\text { 1. } 16 \text { days E.O. } \\
5 \text { days E.O.+ } \\
\text { strol acetate } 4 \mathrm{mg}- \\
\text { 2. } 16 \text { days E.O. } \\
5 \text { days E.O. } \\
\text { strol acetate } 5 \mathrm{mg} \text { - }\end{array}$ & $\begin{array}{l}0.75 \\
0.05 \\
0.1 \\
0.1\end{array}$ & 28 & 0.5 & 6 & 6 & 6 \\
\hline
\end{tabular}

* Compounds classified as strongly progestogenic-B.T.B. 0-3\%.

TABLE VI.-Incidence of Dilated Sinusoids and Leg Symptoms in Women Who Had Biopsies During the First Yeal of Therapy on Oral Contraceptive Compounds Containing Mestranol

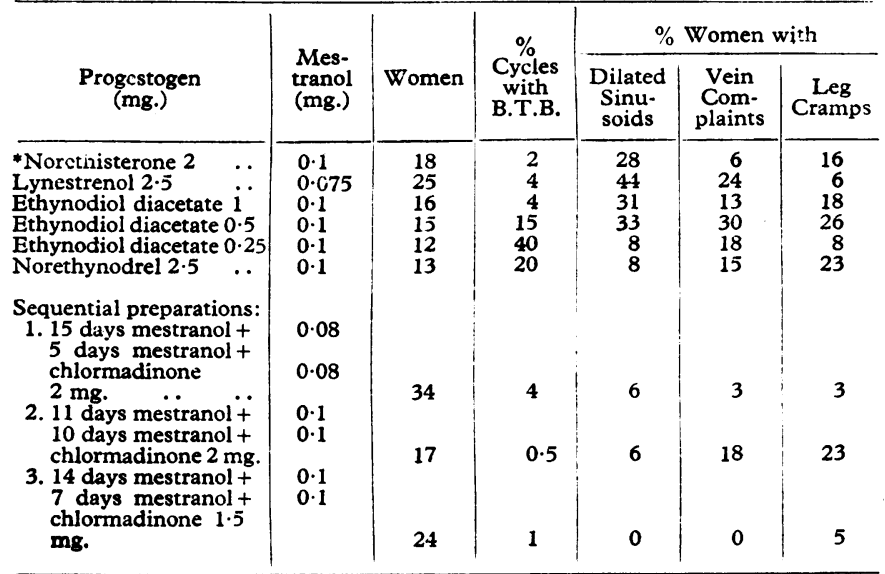

- Strongly progestogenic compounds-B.T.B. 0-3\%.

\section{Stromal Condensation}

It was observed that some women complaining of leg cramps had consecutive biopsies with stromal condensation round the sinusoids. The incidence of women noting leg cramps during their first year is compared with the incidence of specimens with stromal condensation obtained from these women (Table VII). While not every women with sinusoid thickening complained of leg cramps, $70 \%$ of those with leg cramps had stromal condensation in one or more biopsies. With norethisterone acetate $1 \mathrm{mg}$. and ethinyloestradiol $0.075 \mathrm{mg}$. therapy leg cramps were particularly noticeable, affecting nearly half the women, and this product was discontinued after one year. There was no direct relation between arteriolar development and leg cramps, and the same women did not usually have both. A pretrial history of leg cramps was not obtained, but retrospective questioning revealed that few women remembered troublesome cramps except in pregnancy.
TABLE VII.-Incidence of Stromal Condensation and Leg Cramps in Women Who Had Biopsy Specimens in Their First Year of Therapy

\begin{tabular}{|c|c|c|c|c|c|c|c|c|}
\hline \multirow[t]{2}{*}{ Product (mg.) } & \multirow{2}{*}{$\begin{array}{c}\text { No. } \\
\text { of } \\
\text { Women }\end{array}$} & \multicolumn{2}{|c|}{$\begin{array}{l}\text { Well- } \\
\text { developed } \\
\text { Arterioles }\end{array}$} & \multicolumn{2}{|c|}{$\begin{array}{c}\text { (a) } \\
\text { Stromal } \\
\text { Condensation } \\
\end{array}$} & \multicolumn{2}{|c|}{$\begin{array}{c}\text { (b) } \\
\text { Leg } \\
\text { Cramps }\end{array}$} & \multirow{2}{*}{$\begin{array}{l}\text { Both } \\
\text { (a) } \\
\text { and } \\
\text { (b) } \\
\text { No. }\end{array}$} \\
\hline & & No. & $\%$ & No. & $\%$ & No. & $\%$ & \\
\hline \\
\hline $\begin{array}{c}\text { mestranol } 0.1 \mathrm{mg} . \\
\text { (Ortho-Novin) } \\
\text { Lynestrenol } 2.5+\end{array}$ & 18 & 2 & 11 & 1 & 6 & 1 & 6 & 0 \\
\hline $\begin{array}{l}\text { mestranol } 0.075 \\
\text { mg. (Lyndiol 2.5) }\end{array}$ & 25 & 9 & 36 & 6 & 24 & 4 & 16 & 3 \\
\hline $\begin{array}{l}\text { Norgestrel } 1+\text { E.O. } \\
0.05 \mathrm{mg} .\end{array}$ & 20 & 10 & 50 & 6 & 30 & 4 & 20 & 3 \\
\hline $\begin{array}{l}\text { Norethisterone ace- } \\
\text { tate 4+E.O. 0.05 } \\
\text { mg. (Anovlar) . }\end{array}$ & 32 & 12 & 38 & 4 & 12 & 2 & 6 & 1 \\
\hline $\begin{array}{l}\text { Norethisterone ace- } \\
\text { tate + E.O. } 0.075\end{array}$ & & & & & & & & \\
\hline $\begin{array}{c}\text { mg. } \\
\text { Norethisterone ace- }\end{array}$ & 28 & 11 & 40 & 13 & 46 & 13 & 46 & 9 \\
\hline $\begin{array}{l}\text { tate } 1+\text { E.O. } 0.09 \\
\text { mg. }\end{array}$ & 20 & 12 & $\epsilon_{0}$ & 4 & 20 & 4 & 20 & 2 \\
\hline \multicolumn{9}{|l|}{$\begin{array}{l}\text { Sequential prepara- } \\
\text { tions: } \\
11 \text { days mestranol } \\
0 \cdot 1 \text { and } 10 \text { days } \\
\text { mestranol } 0 \cdot 1+ \\
\text { chlørmadinone }\end{array}$} \\
\hline $\begin{array}{l}2 \mathrm{mg} . \\
0.1 \text { and } 7 \text { days } \\
\text { mestranol } 0 \cdot 1+ \\
\text { chlormadinone }\end{array}$ & 17 & 4 & 23 & 4 & 23 & 4 & 23 & 4 \\
\hline $\begin{array}{l}1.5 \mathrm{mg} \text {. } \\
\text { 3. } 16 \text { days E.O. } 0.1 \\
\text { and } 5 \text { days E.O. } \\
0.1 \text { + megestrol }\end{array}$ & 24 & 6 & 25 & 1 & 5 & 1 & 5 & 0 \\
\hline acetate $5 \mathrm{mg}$. .. & 17 & 5 & 29 & 2 & 11 & 1 & 6 & 1 \\
\hline
\end{tabular}

\section{Effect of Prolonged Therapy}

As the cases of phlebitis and thrombosis in this trial developed after the first year the effect of prolonged therapy on vein complaints and sinusoid changes was studied. Table VIII shows the effect of four years' treatment with norethynodrel $2.5 \mathrm{mg}$. and mestranol $0.1 \mathrm{mg}$. (Conovid E) and norethisterone $2 \mathrm{mg}$. and mestranol $0.1 \mathrm{mg}$. (Ortho-Novin). Both products were well tolerated in the first year, only $10 \%$ of the women withdrawing because of side-effects. In each case the proportion of biopsies showing dilated sinusoids and stromal condensation increased after the first 12 cycles, as did the incidence of vein complaints among these women. One woman had four biopsy specimens taken at the same phase of different cycles while she was taking Ortho-Novin. These showed small sinusoids in cycle 6 , stromal condensation in cycle 13, dilated sinusoids in cycle 20, and very large sinusoids in cycle 43 . During cycle 43 she developed bilateral phlebitis and discontinued medication. Another four women had biopsies taken during the same month that they developed phlebitis or thrombosis, and all had sinusoid changes.

TABle VIII.-Effect of Prolonged Therapy on Endometrial Sinusoids

\begin{tabular}{|c|c|c|c|c|c|c|c|c|c|}
\hline \multirow{2}{*}{ Cycles } & \multirow{2}{*}{$\begin{array}{c}\text { No. of } \\
\text { Women } \\
\text { Examined }\end{array}$} & \multicolumn{2}{|c|}{$\begin{array}{l}\text { Dilated } \\
\text { Sinusoids }\end{array}$} & \multicolumn{2}{|c|}{$\begin{array}{c}\text { Stromal } \\
\text { Condensation }\end{array}$} & \multicolumn{2}{|c|}{$\begin{array}{c}\text { Vein } \\
\text { Complaints }\end{array}$} & \multicolumn{2}{|c|}{$\begin{array}{c}\text { Leg } \\
\text { Cramps }\end{array}$} \\
\hline & & No. & $\%$ & No. & $\%$ & No. & $\%$ & No. & $\%$ \\
\hline \multicolumn{10}{|c|}{ Norethynodrel $2.5 \mathrm{mg} .+$ Mestranol $0.1 \mathrm{mg}$. } \\
\hline $\begin{array}{r}1-12 \\
13-24 \\
25-51\end{array}$ & $\begin{array}{r}13 \\
18 \\
8\end{array}$ & $\begin{array}{l}2 \\
7 \\
4\end{array}$ & $\begin{array}{l}15 \\
3) \\
50\end{array}$ & $\begin{array}{l}1 \\
4 \\
5\end{array}$ & \begin{tabular}{r|}
82 \\
22 \\
62
\end{tabular} & $\begin{array}{l}2 \\
7 \\
4\end{array}$ & $\begin{array}{l}15 \\
39 \\
50\end{array}$ & $\begin{array}{l}2 \\
6 \\
4\end{array}$ & $\begin{array}{l}15 \\
33 \\
50\end{array}$ \\
\hline \multicolumn{10}{|c|}{ Norethisterone $2 \mathrm{mg} .+M \times s t r a n o l 0.1 \mathrm{mg}$} \\
\hline $\begin{array}{r}1-12 \\
13-24 \\
25-43\end{array}$ & $\begin{array}{r}19 \\
19 \\
2\end{array}$ & $\begin{array}{r}5 \\
10 \\
2\end{array}$ & $\begin{array}{r}28 \\
52 \\
100\end{array}$ & $\begin{array}{l}1 \\
6 \\
0\end{array}$ & $\begin{array}{r}5 \\
31 \\
0\end{array}$ & $\begin{array}{l}1 \\
6 \\
2\end{array}$ & $\begin{array}{r}5 \\
31 \\
100\end{array}$ & $\begin{array}{l}0 \\
2 \\
0\end{array}$ & $\begin{array}{r}0 \\
10 \\
0\end{array}$ \\
\hline
\end{tabular}

\section{Discussion}

The clinical results show that vein complaints, leg cramps, and thrombophlebitis are significantly more frequent with the less strongly progestogenic oral contraceptives containing mestranol 
than with the other five groups of oral contraceptives used in this trial.

The different results with mestranol and ethinyloestradiol could be due to the different chemical composition of these preparations, but as mestranol is converted to ethinyloestradiol in the body they may be a dosage effect. Most tablets containing ethinyloestradiol have a $0.05-\mathrm{mg}$. dose, whereas $0.1 \mathrm{mg}$. is the usual dose of mestranol. One would expect a larger dose of oestrogen to have a greater effect on veins in view of the findings of Daniel et al. (1967) and Oliver (1967). They reported that synthetic oestrogens given alone seem to increase the risk of thromboembolism. In this study the most strongly oestrogenic preparations, the sequential regimens, did not have the highest incidence of vein complaints and no cases of thrombophlebitis occurred.

The histological results show that the sequential regimens do not dilate the endometrial sinusoids to any great extent. This is in contrast to the strongly progestogenic and most of the intermediate compounds, which produce a high incidence of dilated sinusoids. Nevertheless, the strongly progestogenic compounds, in spite of having an immediate effect on the endometrial sinusoids, have a low incidence of vein complaints in the first few years. It may be that, just as a higher dose of oestrogen seems to protect against the depressive effect of high monoamine oxidase activity produced by strongly progestogenic pills (Grant and Pryse-Davies, 1968), so a higher dose of progestogen may protect against generalized venous dilatation.

There are individual examples of the effect of various doses of progestogen given with a constant dose of oestrogen which support this view. For example, one woman had sore veins, feet cramps, numbness on an $0 \cdot 1-\mathrm{mg}$. dose, loss of libido with a 1-mg. dose, and hreak-through bleeding with a $0.5-\mathrm{mg}$. dose. The oestrogen was $0.1 \mathrm{mg}$. of mestranol in each case.

Stromal condensation round the endometrial sinusoids may also be an important indication of the tendency of any preparation to cause vein changes. Just as the first-year incidence of headaches on oral contraceptives correlates with the incidence of well-developed arterioles, so the incidence of leg cramps and stromal condensation show some correlation. These effects appear to be specific for each combination of progestogen and oestrogen and are not strictly related to hormone balance. The intermediate mestranol group, which had the highest incidence of thrombophlebitis, also had the highest incidence of leg cramps. It seems possible that leg cramps may be caused by thickening of the venule walls preventing absorption of metabolites.

Poller and Thomson (1966) found that women taking various combined oral contraceptives had increased levels of factors VII and X. The rise in factor VII (at the end of two years) was similar to that in the third trimester of pregnancy and appeared to be cumulative. In a preliminary report on results with a progestogen only (chlormadinone acetate $0.5 \mathrm{mg}$.) Poller
(1968) found that there was no rise in the clotting factors after three months, and the women who started with the high levels following conventional oestrogen/progestogen administration were showing a return to normal levels.

Hence changes in the blood and blood vessels are probably occurring simultaneously and increasing with time. The extent of the vessel changes appears to depend on: (1) chemical composition of steroids used, (2) exact dose of each, (3) hormone balance of the product, and (4) susceptibility of the individual woman, which in turn depends on age, pretreatment vascular state, and duration of therapy.

A product which is well tolerated in the first years is perhaps more likely to be taken longer by vascularly reactive women who are more susceptible to generalized side-effects. Thus a trial of several years' duration is desirable to establish the effect of each oral contraceptive.

I am grateful to Dr. Eleanor Mears and Dr. Hilary Hill for their interest and encouragement in this study, which was supported financially by the Council for the Investigation of Fertility Control and the Lalor Foundation. I should also like to acknowledge the help from Dr. Barbara Schooling, Dr. Rita Tozer, Dr. Sheila Cochrane, Dr. John Scott-Wilson, and Sister Barbara Lamb, and also thank Mrs. Ann Davis for advice on statistical analysis of the results.

\section{REFERENCES}

Daniel, D. G., Campbell, H., and Turnbull, A. C. (1967). Lancet, 2, 287.

Drill, V. A. (1966). Oral Contraceptives, p. 173. New York, McGrawHill.

Grant, E. C. G. (1967). Fournal of Obstetrics and Gynaecology of the British Commonwealth, 74, 908.

Grant, E. C. G. (1968). British Medical fournal, 3, 402.

Grant, E. C. G., and Pryse-Davies, J. (1968). British Medical fournal, 3, 777.

Inman, W. H. W., and Vessey, M. P. (1968). British Medical fournal, 2, 193.

Mears, E. (1961). British Medical fournal, 2, 1179.

Mears, E. (Editor) (1965). Handbook on Oral Contraception, p. 39. London, Churchill.

Mears, E. (1967). In Fertility and Sterility: Proceedings of the 5th World Congress, edited by B. Westin and N. Wiquist, p. 1005. Amsterdam, Excerpta Medica.

Medical Research Council (1967). British Medical fournal, 2, 355.

Oliver, M. F. (1967). Lancet, 2, 510.

Poller, L. (1968). Paper presented at Symposium on Chlormadinone Acetate, Cambridge. In press.

Poller, L., and Thomson, J. M. (1966). British Medical fournal, 2, 23.

Royal College of General Practitiuners (1967). Fournal of the College of General Practitioners, 13, 267.

U.S. Food and Drug Administration (1963). Final Report on Enovid by the Ad Hoc Committee for the Evaluation of a Possible Etiologic Relation with Thromboembolic Conditions. Washington, U.S.A.

U.S. Food and Drug Administration (1966). Report on the Oral Contraceptives, by an Advisory Committee on Obstetrics and Gynecology. Washington, U.S.A.

Vessey, M. P., and Doll, R. (1968). British Medical fournal, 2, 199. 